\title{
REFLEXÕES SOBRE AS TECNOLOGIAS NA EDUCAÇÃO A PARTIR DE UMA ABORDAGEM CRÍTICA
}

\author{
Carla Milbradt \\ Mestranda em Educação - Universidade La Salle - Canoas - RS - Brasil \\ cal_milbradt@hotmail.com
}

\begin{abstract}
Para citar - ABNT NBR 6023:2018
MILBRADT, Carla. Reflexões sobre as tecnologias na educação a partir de uma abordagem crítica. Cadernos de Pósgraduação, São Paulo, v. 19, n. 1, p. 88-90, jan./jun. 2020. Resenha. Disponível em:

https://doi.org/10.5585/cpg.v19n1.16918.
\end{abstract}

A obra (Re)pensar as tecnologias na educação a partir da teoria crítica, dos autores Adilson Cristiano Habowski e Elaine Conte, publicada pela Editora Pimenta Cultural em 2019, contribui para avaliar a atual sociedade do conhecimento, as novas configurações do processo educacional, tais como a tecnologização, o hibridismo, a globalização, a internacionalização, a multi e interculturalidade, a ilusão da neutralidade técnica e operacionalidade. A obra se organiza em duas partes nas quais se desvelam a dimensão formativa e de renovação do sentido das tecnologias para o pensar educativo.

Na primeira parte, para abordar essas inquietações e discuti-las de modo compreensivo, os autores utilizam a abordagem hermenêutica, em função das contradições e tensões presentes nos textos e discursos sobre o assunto. Inicialmente apresentam um desenho de uma pesquisa hermenêutica com um mapeamento de teses de doutorado, em que demonstram a preocupação acerca do que já vem sendo produzido nessa área temática, situando o leitor no contexto das tecnologias digitais, bem como verificando as pesquisas e discutindo as produções científicas do país. Assim, analisam as teses produzidas na área de tecnologia e educação, nos Programas de PósGraduação em Educação das universidades públicas brasileiras, disponíveis no portal da Biblioteca Digital Brasileira de Teses e Dissertações (BDTD, link: http://bdtd.ibict.br/). Os autores coletaram oitenta (80) teses, no período de 2012 a 2016, tendo como descritores: educação e tecnologia. Com base nos dados coletados, perceberam investidas em relação ao processo mais humanizador e emancipador quanto ao uso das tecnologias na educação, sobretudo na relação dialética humanocomputador e no papel ativo do educador nesse processo. Identificam caminhos para a compreensão dos problemas contemporâneos na educação e para atender as demandas éticoformativas das interações que se estabelecem nos processos de educar e que trazem a exigência ética da relação entre sujeitos, tanto no acesso ao conhecimento, quanto nos movimentos de 
(re)construção e interpretação das linguagens tecnológicas (consequências de caráter social e nãolinear).

A segunda parte da obra pauta-se na perspectiva de justificação temática e aprofundamento teórico-reflexivo acerca das tecnologias digitais e suas implicações no ambiente educativo, no que tange ao ensino, aprendizagem, formação docente e políticas educacionais. Os autores fazem uma interlocução com a historicidade da teoria crítica, proporcionando ao leitor uma compreensão de qual ponto epistemológico se observa nas discussões acerca das tecnologias digitais. Tudo isso para mostrar os processos de formação com as tecnologias e o panorama a ser pensado e explorado no campo filosófico, em diálogo com a pluralidade das pesquisas em educação.

A partir dos elementos da Teoria Crítica e da Filosofia da Tecnologia e suas interfaces com as tecnologias digitais na educação, os autores apresentam os limites e desafios ao progresso técnico da instrumentalização vital, para esboçar práticas pedagógicas cotidianas que criem vínculos ou amálgamas com as experiências humanas, para não esvaziar as relações de diálogo e de resistências socioculturais. Aqui colocam em questão um olhar crítico sobre o interesse e fascínio pelas tecnologias na educação, ao levar em consideração os perigos de alienações, inércias de discussão e semiformação difundida pela indústria cultural de interesses mercadológicos.

Os autores defendem que a tecnologia precisa ser repensada na formação de professores como um espaço de construção da opinião esclarecida e uma condição de possibilidade para restauração dos conhecimentos em processos de democracia participativa de professores, superando o domínio estritamente técnico do saber, no sentido de mediar mundos, integrar diálogos interculturais e reconstruir formas de pensar e agir dos sujeitos. Desse modo, não se trata de simplesmente de garantir que as inovações tecnológicas entrem na cultura escolar, mas de aprender com o outro a ressignificar o antigo, resistindo ao ensino fabricado para integrar as inteligências humanas. Trata-se de dar sentido às tecnologias a partir de intencionalidades pedagógicas coerentes com o exercício comunicativo e (auto)crítico, pois a tecnologia não pode ser tomada como um fim em si, mas como um meio provocativo, reflexivo e criativo para os processos de educar.

Nas considerações finais, os autores indicam a necessidade de permanecer com um olhar (auto)crítico frente a essa cultura hiperconectada e desorientada, de incertezas e de uma lógica apressada de cursos técnico-instrumentais, que são constantemente restauráveis, instrumentalizados e automatizáveis até pelo conhecimento científico, culminando no tecnocapitalismo ou na pseudociência. Indicam que a saída não está em proibir o uso das tecnologias digitais, mas gira em torno da supervisão e reflexão no momento da experimentação, pois esses artefatos são o patrimônio comum da humanidade. A educação surge como possibilidade 
de uma formação problematizadora que articula racionalidade, historicidade e sensibilidade, na recriação e ressignificação do pensar e agir coletivo.

A obra, como um todo, apresenta um esforço didático e acadêmico-científico que valoriza as discussões sobre as tecnologias digitais, suas potencialidades, fragilidades e necessidades para a utilização nos processos de ensino e aprendizagem, bem como as repercussões para a formação de professores (HABOWSKI; CONTE; TREVISAN, 2019). Por fim, há o reconhecimento da necessidade de problematizar as tecnologias, dada a desfiliação e vulnerabilidade dos educadores e educandos em meio à expropriação da experiência tecnológica e ao conformismo sistêmico. Tratase de um trabalho inspirador, que faz com que o leitor se sinta parte do processo construtivo e analítico do texto. Os autores conseguem envolver o leitor por meio de uma abordagem pautada na criticidade, nas indagações e, especialmente, na atitude hermenêutica, de modo a contextualizar, a compreender e ao mesmo tempo nos desestabilizar sobre as nuances das tecnologias digitais na contemporaneidade. Assim, vale a pena a leitura que permite também examinar os debates sobre as experiências pedagógicas no campo sensível da práxis tecnológica, mantendo acesa a chama do conhecimento nessas facetas encantadoras das tecnologias sociais e digitais, do pensar sensível às múltiplas linguagens do agir humano.

\section{Referências}

HABOWSKI, Adilson Cristiano; CONTE, Elaine. (Re)pensar as tecnologias na educação a partir da teoria crítica. São Paulo: Pimenta Cultural, 2019.157p. DOI: 10.31560/pimentacultural/2019.546

HABOWSKI, Adilson Cristiano; CONTE, Elaine; TREVISAN, Amarildo Luiz. Por uma cultura reconstrutiva dos sentidos das tecnologias na educação. Educação \& Sociedade, Campinas, v. 40, n. 2, p. 1-18, 2019. DOI: 10.1590/es0101-73302019218349 